\title{
Beware of Fixation-It Might Affect Your Experiments
}

\author{
Myoung-Ryoul Park ${ }^{1,2}$ and Karl H. Hasenstein ${ }^{1}$
}

${ }^{I}$ Biology Department, University of Louisiana at Lafayette, Lafayette, LA; ${ }^{2}$ National Institute of Crop Science (NICS), RDA, Suwon, 16429, Republic of Korea

\begin{abstract}
Because of difficulties during the fixation in space and the often reported enhanced expression of stress-related genes in space experiments, we investigated the possible effect of fixation on gene expression. Comparing two fixatives (RNAlater ${ }^{\circledR}$ and $70 \%$ ethanol), two-day-old Brassica rapa seedlings were either fixed by gradual exposure or immediate and complete immersion in fixative for two days. Neither fixative yielded high amounts of rRNA; RNAlater ${ }^{\circledR}$ resulted in higher RNA yield in shoot tissue but qPCR data showed higher yield in ethanol-fixed material. qPCR analyses showed strongly enhanced transcripts of stress-related genes, especially in RNAlater ${ }^{\circledR}$-fixed material. The data suggest that fixation artefacts may be partially responsible for effects commonly attributed to space syndromes.
\end{abstract}

\section{INTRODUCTION}

Biological experiments in space inevitably require post-flight processing of the tested material because processing in space is currently

Key words: Ethanol; Fixation; Gene Expression; Spaceflight; RNAlater®

Correspondence to: Karl H. Hasenstein

Biology Depar®ent

University of Louisiana at Lafayette

Lafayette, LA 70504-46302

Telephone: 337-482-6750

E-mail: hasenstein@louisiana.edu not possible. Therefore, specimen must be preserved on-orbit for future processing and analyses in ground laboratories. Preservation may be based upon freezing in MELFI (Minus Eighty Degree Laboratory Freezer for International Space Station (ISS) (Paul et al., 2005a)), or chemical fixation in aldehyde-based fixatives. While typical laboratory protocols readily enable flash-freezing (submerging specimen in liquid nitrogen), such procedures are difficult to perform in the weightlessness environment of the Space Station. MELFI storage and preservation is limited and difficult for large samples and does not provide the fast freezing obtained with submersing samples in liquid nitrogen. Space experiments typically require gene transcription or expression analyses that require preservation in solutions that are safe to handle, inhibit RNAses, preserve tissue, are non-toxic or flammable, and do not require freezing. US patent 6204375 describes "Methods and reagents for preserving RNA in cell and tissue samples"; this patent was later commercialized as RNAlater ${ }^{\circledR}$. According to Sigma Corporation's data sheet, this fixative "rapidly permeates tissue to stabilize and protect cellular RNA in situ in unfrozen specimens. RNAlater ${ }^{\circledR}$ eliminates the need to immediately process tissue specimens or to freeze samples in liquid nitrogen for later processing." These claims made RNAlater ${ }^{\circledR}$ a popular fixative for numerous applications (Abbaraju et al., 2011; Botling et al., 2009; Dunmire et al., 2002; Fajardy et al., 2009; Grotzer et al., 2000; Millar et al., 2011; Nsubuga et al., 2004) and it has found wide 


\section{Park and Hasenstein -- Fixation Artefacts}

application in space biology experiments (Fengler et al., 2015; Ferl et al., 2015; Ferl et al., 2011; Gupta et al., 2015; Paul et al., 2005b; Pietsch et al., 2013) and corresponding ground studies (Kittang et al., 2010; Páska et al., 2004; Riesgo et al., 2012; Wang et al., 2006).

Although the convenience of its use, generic applicability, and long-term storage capabilities established RNAlater ${ }^{\circledR}$ as a universally accepted fixative (Riesgo et al., 2012), investigators are not typically aware of complications related to this fixative. RNAlater ${ }^{\circledR}$ is a buffered ( $\mathrm{pH}$ 5.2), essentially saturated solution of ammonium sulfate, and therefore has an extremely high osmotic concentration. This property may be of limited consequence for ground applications when samples can be rapidly and reliably submersed in excess of fixative. However, in the weightless conditions of space, fluid flow may not be favorable for rapid and complete fixation. In space, fluids do not necessarily fill volumes in a predictable direction; rather liquids follow surfaces and hydrophobicity and wettability become determining factors for their distribution. In addition, plant tissue, in particular, is typically grown on aqueous surfaces (agar or other watercontaining substrate) that dilutes the fixative and prevents rapid immersion. Lastly, filling of available volumes may not be complete because of the inclusion of air that cannot escape experimental containers. The combination of these conditions is likely to affect the distribution, rate, and concentration of fixative as it interacts with the tissue to be fixed. The result is either gradual or, at least initially, intermittent exposure to fixative.

A consequence of such delayed or gradual exposure to fixative becomes important as biological systems are sensitive to osmotic changes, which leads to rapid and significant upregulation of stress-related genes. Osmotic stress especially leads to a generic upregulation of heat-shock proteins (Almoguera et al., 2015; Dunaeva and Adamska, 2001) that often induce down-stream effects (Dantán-González et al., 2001). Thus, fixation in RNAlater ${ }^{\circledR}$ in space may induce non-specific stress responses that are not part of the actual 'space syndrome,' but the result of space-specific slow or delayed fixation. Slow fixation may cause unintended but significant responses as a result of the fixation process.
Because retrieval of space experiments depends on launch and landing schedules that are independent of the specific experiment, tissue typically has to be stored for extended times in fixative. Thus, in addition to the high osmolarity of RNAlater ${ }^{\circledR}$, the high salt concentration can lead to corrosive effects when metal surfaces react with fixative. Such interactions may release ammonium that changes the $\mathrm{pH}$, builds up pressure, and affects the stability of RNA.

To investigate the susceptibility of the fixation process on the rate of addition of RNAlater ${ }^{\circledR}$, and to examine alternative fixative, we examined the effect of different rates of fixation with RNAlater ${ }^{\circledR}$ and $70 \%$ ethanol on the transcription of several genes in Brassica rapa (Brassica) seedlings. The results show that the fixation process has profound effects on transcription levels.

\section{MATERIALS AND METHODS}

\section{Plant Material}

Brassica seeds were mounted between germination paper in seed cassettes, as used for the Biotube-MICRO experiment on Space-X3 (Figure 1). Germination was initiated by adding $400 \mu \mathrm{L}$ water to each cassette. The seed cassettes were kept in petri dishes in the dark and allowed to germinate at $27^{\circ} \mathrm{C}$ and grown for $48 \mathrm{~h}$.

\section{Fixation}

Seedlings were either fixed in RNAlater ${ }^{\circledR}$ (25 $\mathrm{mM}$ Na-citrate, $10 \mathrm{mM} \quad \mathrm{Na}_{2}$ EDTA, $76 \mathrm{~g}$ $\left(\mathrm{NH}_{4}\right)_{2} \mathrm{SO}_{4}$ per $100 \mathrm{ml}$ solution, $\mathrm{pH}$ 5.2) or $70 \%$ $(\mathrm{v} / \mathrm{v})$ ethanol. Seedlings that were immersed completely into the respective fixative (fast fixation) served as controls. 'Slow' fixation involved submersing the apical $1 \mathrm{~mm}$ of each of 20 Brassica seedlings in each fixative for one minute, then the whole seedling was put into each fixative for five seconds, removed for 30 seconds, dipped into fixative a second time for five seconds, and after 30 seconds in air completely submersed in fixative. Both fast and slow fixation samples were kept for $24 \mathrm{~h}$ in the respective fixative.

\section{Sample Preparation and Extraction}

The seedlings were separated in roots and shoot tissue (hypocotyls, excluding cotyledons) 


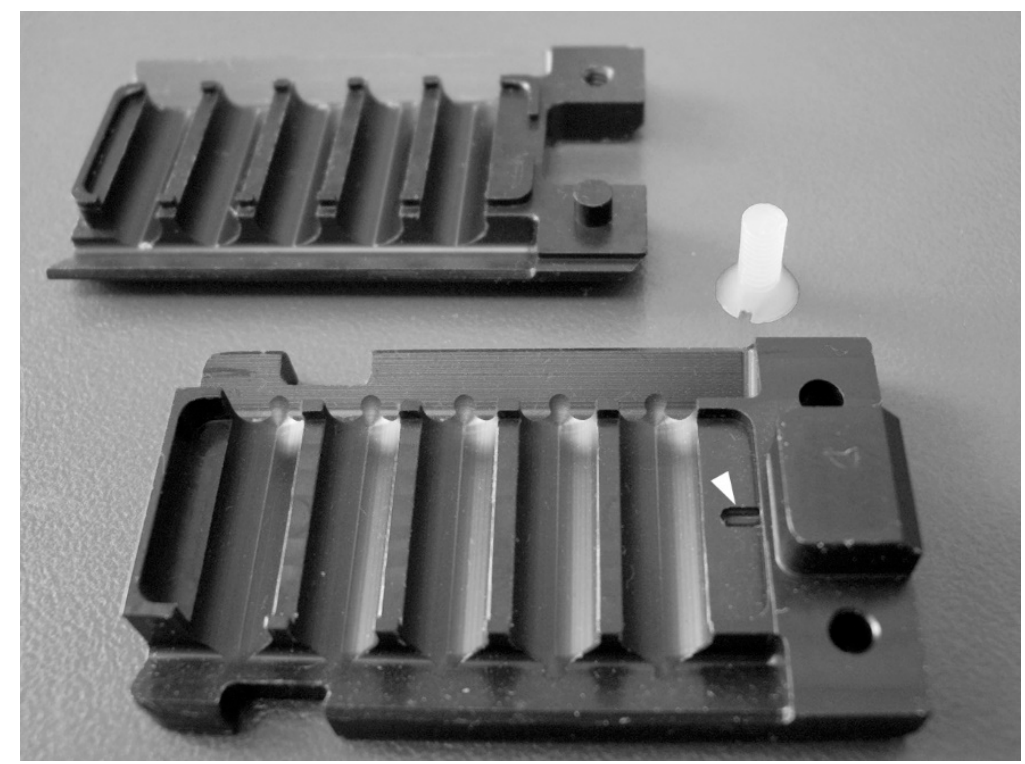

Figure 1. Seed cassettes used for the germination of Brassica rapa. This hardware was part of the experiment "Magnetophoretic Induction of Curvature in Roots" that flew on Space-X3. The base (bottom) secures the top half of the cassette with peg and nylon screw. Seeds were germinated between 'germination paper' (not shown), such that seeds were positioned in one of the grooves. Germination was initiated by adding water through a port (arrow) on the base.

and the RNA from all samples was extracted using the Qiagen RNeasy Plant Mini Kit, according to the manufacturer's instructions.

\section{Evaluation}

\section{Total RNA}

The extracted RNA was analyzed on a QIAxcel RNA high-resolution capillary electrophoresis system.

\section{Reverse Transcription}

Total RNA was reversed transcribed using a High Capacity cDNA Reverse Transcription Kit (Applied Biosystems, USA) in $20 \mu \mathrm{L}$ volumes containing $2 \mu \mathrm{g}$ total RNA, $3.8 \mu \mathrm{L}$ reverse transcription mixture (final concentration: $1 \mathrm{mM}$ dNTP, 1X reverse transcription buffer, and $50 \mathrm{U}$ Multiscribe $^{\mathrm{TM}}$ reverse transcriptase), $2 \mu \mathrm{l} 5 \mu \mathrm{M}$ oligo dT(20), and diethylpyrocarbonate (DEPC)treated water to $20 \mu \mathrm{L}$. Reverse transcription was performed at $25^{\circ} \mathrm{C}$ for $10 \mathrm{~min}$, then at $37^{\circ} \mathrm{C}$ for 2 $\mathrm{h}$, after which the reverse transcriptase was inactivated by heating the samples to $85^{\circ} \mathrm{C}$ for 5 min. The synthesized cDNA was diluted 1:10 in DEPC-treated water and stored at $-20^{\circ} \mathrm{C}$.

\section{qPCR}

ACT7, SUS, UBQ, COX, HSP70, and HSP90 were quantified with primers listed in Table 1. Primers were for amplicons that had no bias toward the 3 ' end of the coding data sequence (Table 1). The reaction mixture $(10 \mu \mathrm{L}$, final concentration and volumes: 2X Power SYBR Green PCR Master Mix ( $5 \mu \mathrm{L}), 200 \mathrm{nM}$ primers ( $1 \mu \mathrm{L}, 100 \mathrm{nM}$ each), $2 \mu \mathrm{L}$ cDNA (adjusted to 0.5 $\mu \mathrm{g} / \mu \mathrm{l}$ ), and $1 \mu \mathrm{L}$ water was activated (10 min at $\left.95^{\circ} \mathrm{C}\right)$ and cycled between $95^{\circ} \mathrm{C}(15 \mathrm{~s})$ and the respective annealing temperature (Table $1,1 \mathrm{~min}$ ) for 40 cycles using Applied Biosystems StepOne qPCR systems (Applied Biosystems, USA). qPCR products were subjected to melt analysis $\left(60^{\circ} \mathrm{C}\right.$ $95^{\circ} \mathrm{C}$ at $3^{\circ} \mathrm{C} \mathrm{min}^{-1}$ ) and purified using the QIAquick PCR Purification Kit (Qiagen), quantified by spectrophotometry (NanoDrop ND1000), and analyzed to confirm the presence of a single product.

\section{Statistical Analysis}

Experiments were repeated three times with eight seedlings each. Statistical analyses were performed with Microsoft Excel (v. 2013). 
Table 1. qPCR conditions of gene models, their accession numbers, primers, annealing temperatures, amplicon size, and qPCR efficiency used for the evaluation of slow and fast fixation. Position refers to the relative distance $R$ of the amplicon center from the 3 ' end of the coding data sequence $\left(R=\left[d 3^{\prime}-A_{c}\right] / C D S\right)$; (i.e., $0 \equiv 3^{\prime}, 100 \equiv 5 '$ ).

\begin{tabular}{|c|c|c|c|c|c|c|}
\hline $\begin{array}{c}\text { Gene } \\
\text { (accession \#) }\end{array}$ & Direction & Sequence & ® (C) & $\begin{array}{l}\text { Amplicon } \\
\text { size (bp)* }\end{array}$ & $\begin{array}{c}\text { Efficiency } \\
\%\end{array}$ & $\begin{array}{c}\text { Position } \\
\% \text { CDS }\end{array}$ \\
\hline ACT7 & Forward & AGCTTCGTGTTGCACCTGAA & 52 & 79 & 104 & 73 \\
\hline (AT5G09810.1) & Reverse & ACATGGCAGGGACATTGAAAG & 52 & & & \\
\hline SUS & Forward & GTTCAACATTGTCTCTCCTGG & 52 & 53 & 103 & 41 \\
\hline (AT5G20830.1) & Reverse & GCTGTAGATGAGCTCCTCGAT & 54 & & & \\
\hline UBQ1 & Forward & GGAGAGCAGTGACACCATCGA & 56 & 78 & 104 & 67 \\
\hline (Z24738.1) & Reverse & GCCAAGGTACGACCATCTTCA & 54 & & & \\
\hline COX1 & Forward & GTTCCGATTCTGATAGGTGCAC & 55 & 116 & 103 & 80 \\
\hline (AY300014.1) & Reverse & ССТАСТTСТАСТАAGGСTGAGC & 55 & & & \\
\hline HSP70 & Forward & GTCATCACTGTGCCTGCTTACT & 55 & 101 & 99 & 67 \\
\hline (NM_118561.2) & Reverse & CATAAGCCAATGAAGCAGCTGTG & 55 & & & \\
\hline HSP90 & Forward & AAGGTGACACTGCTAAGCTTGA & 53 & 96 & 104 & 82 \\
\hline (AT4G24190.1) & Reverse & СTTCСTTGGTCATACCAATACC & 53 & & & \\
\hline
\end{tabular}

*excluding primers

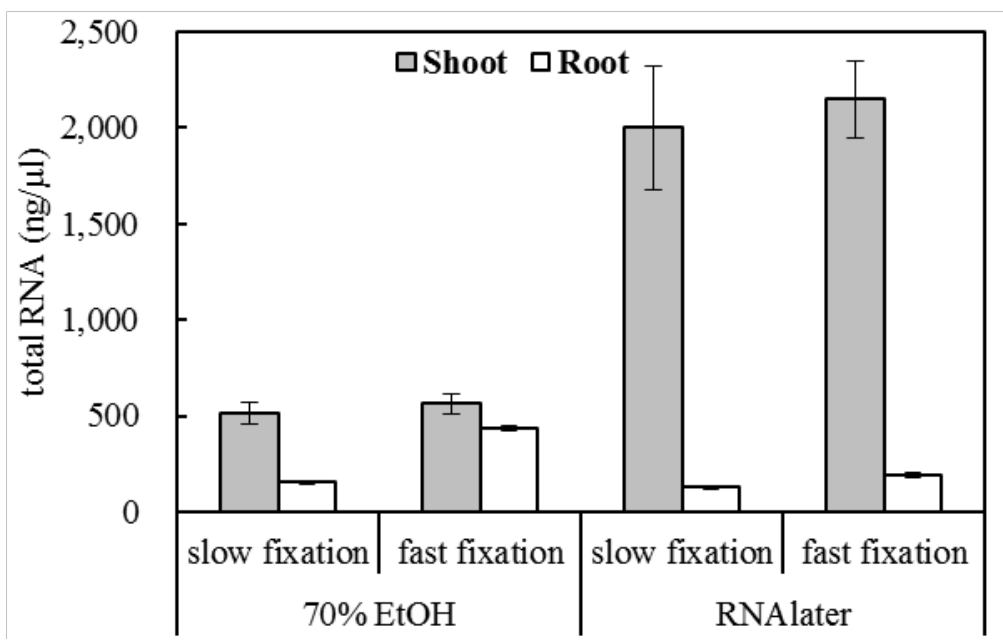

Figure 2. RNA yield of $70 \%$ ethanol or RNAlater ${ }^{\circledR}$-fixed-root or shoot tissue from two-day-old Brassica rapa seedlings that was submersed in fixative gradually (slow fixation), or submersed immediately (fast fixation); details are described in Material and Methods.

Multiple comparisons between qPCR samples were performed by analyses of variance based on three independent biological repeats, each with three technical replicates.

\section{RESULTS}

Fixation in RNAlater ${ }^{\circledR}$ and $70 \%$ ethanol resulted in different yields. RNAlater ${ }^{\circledR}$ showed about four fold higher yield in shoot tissue, but lower yield in root tissue compared with ethanol
(Figure 2). Stressed tissue resulted in reduced yield in both fixatives with the greatest relative reduction seen in root tissues of ethanol fixed samples. However, the yield from root tissue was higher than after RNAlater ${ }^{\circledR}$ fixation. The quality of RNA was assessed by absorbance ratios (Table 2 ) and did not vary based on the mode of fixation or fixative.

The electropherograms of the RNAlater ${ }^{\circledR}$ fixed samples showed consistent patterns of RNA 
in shoot tissue, in both control and stressed samples (Figure 3A). In line with the reduced RNA yield in root tissue, the electropherograms of root RNA were less dense than those of shoot samples. Fixation in ethanol resulted in uniform and discernable bands in both root and shoot tissue. The molecular bands characteristic of rRNA (typically $18 \mathrm{~S}$ and $28 \mathrm{~S}$ ) were absent, but the yield was reasonably high $(>200 \mathrm{ng} / \mu \mathrm{L}$, Figure 2). Despite the apparent higher yield of RNAlater ${ }^{\circledR}$-fixed material, ethanol-fixed tissue produced higher levels of transcripts; the average $\mathrm{Cq}$ value for all genes was 22.62 and 25.25 for ethanol-fixed and RNAlater ${ }^{\circledR}$-fixed material, respectively. The difference is highly significant $\left(\mathrm{F}_{1,23}=39.4, \mathrm{p}<.0001\right)$. In addition to the reduced sensitivity of RNAlater ${ }^{\circledR}$ material, the transcription data showed significantly greater variability compared with ethanol fixed material $\left(\mathrm{F}_{1,23}=8.68, \quad \mathrm{p}<.0001\right)$. This result is also noticeable from the data distribution in Figure 4. These results are not the consequence of the chosen amplicon or reverse cDNA priming because location of the amplicons is not concentrated towards the 3 ' end (last column, Table 1).

Table 2. Absorbance ratios for RNA extractions of samples extracted by Qiagen RNeasy Plant Mini Kit. The $260 / 280$ ratio indicate RNA purity and the $260 / 230$ value corresponds to protein contamination.

\begin{tabular}{ll|cc|cc} 
& & \multicolumn{2}{|c|}{$\mathbf{2 6 0 / 2 8 0}$ ratio } & \multicolumn{2}{c}{$\mathbf{2 6 0 / 2 3 0}$ ratio } \\
& Fixation & Shoot & Root & Shoot & Root \\
\hline \multirow{2}{*}{$70 \%$ EtOH } & slow & $2.11 \pm 0.02$ & $2.10 \pm 0.02$ & $1.81 \pm 0.02$ & $1.81 \pm 0.02$ \\
& fast & $2.10 \pm 0.02$ & $2.11 \pm 0.01$ & $1.80 \pm 0.07$ & $1.84 \pm 0.02$ \\
\multirow{2}{*}{ RNAlater ${ }^{\circledR}$} & slow & $2.10 \pm 0.01$ & $2.13 \pm 0.02$ & $1.81 \pm 0.04$ & $1.84 \pm 0.05$ \\
& fast & $2.11 \pm 0.02$ & $2.07 \pm 0.01$ & $1.82 \pm 0.03$ & $1.86 \pm 0.05$ \\
\hline
\end{tabular}

\section{RNAlater}

\section{Slow fixation}

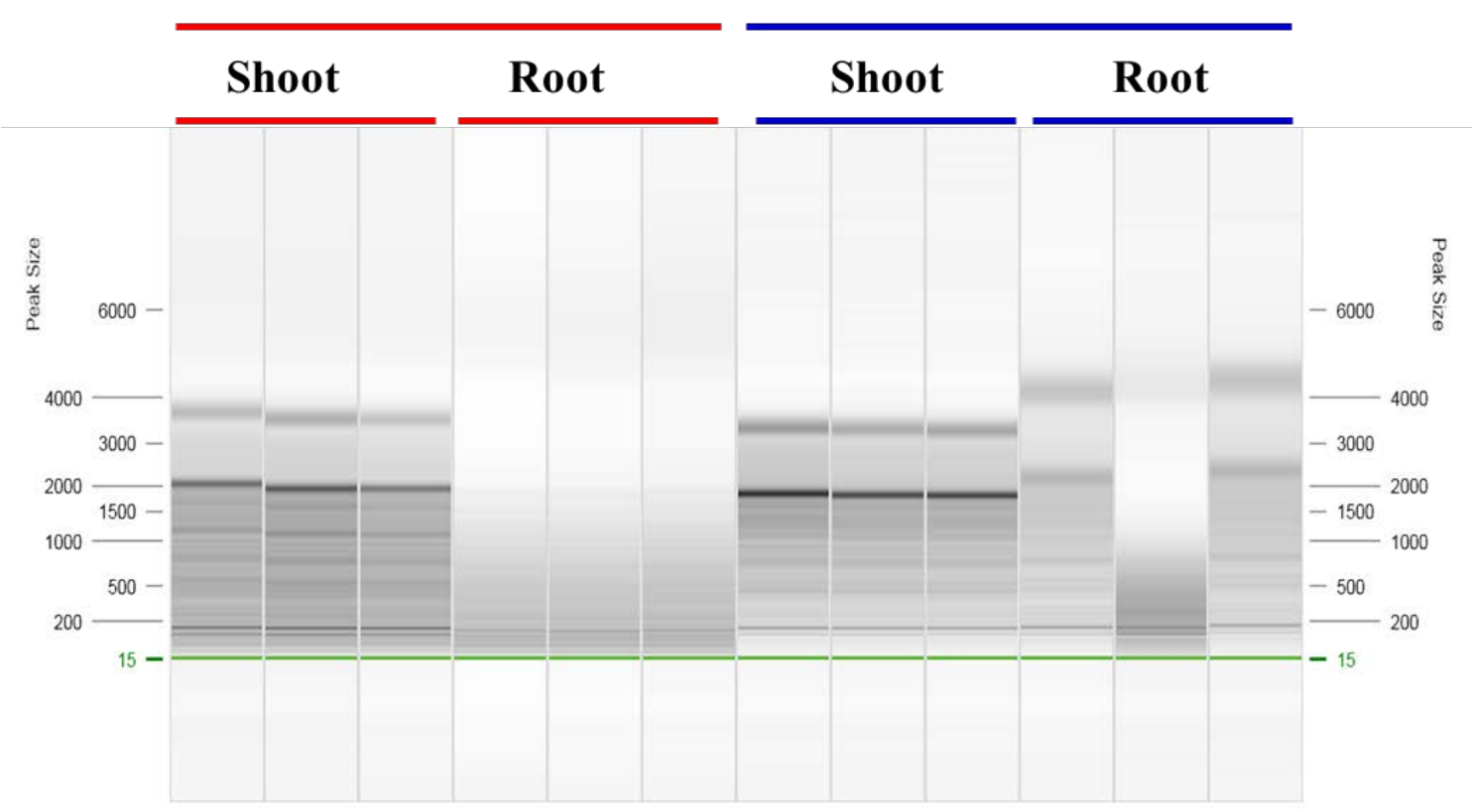

Figure 3A. Electropherogram of total RNA extracted from two-day-old Brassica rapa tissue after RNAlater ${ }^{\circledR}$ fixative was added gradually (slow fixation), or the tissue was immersed completely (fast fixation). 


\section{$70 \%$ Ethanol}

Slow fixation

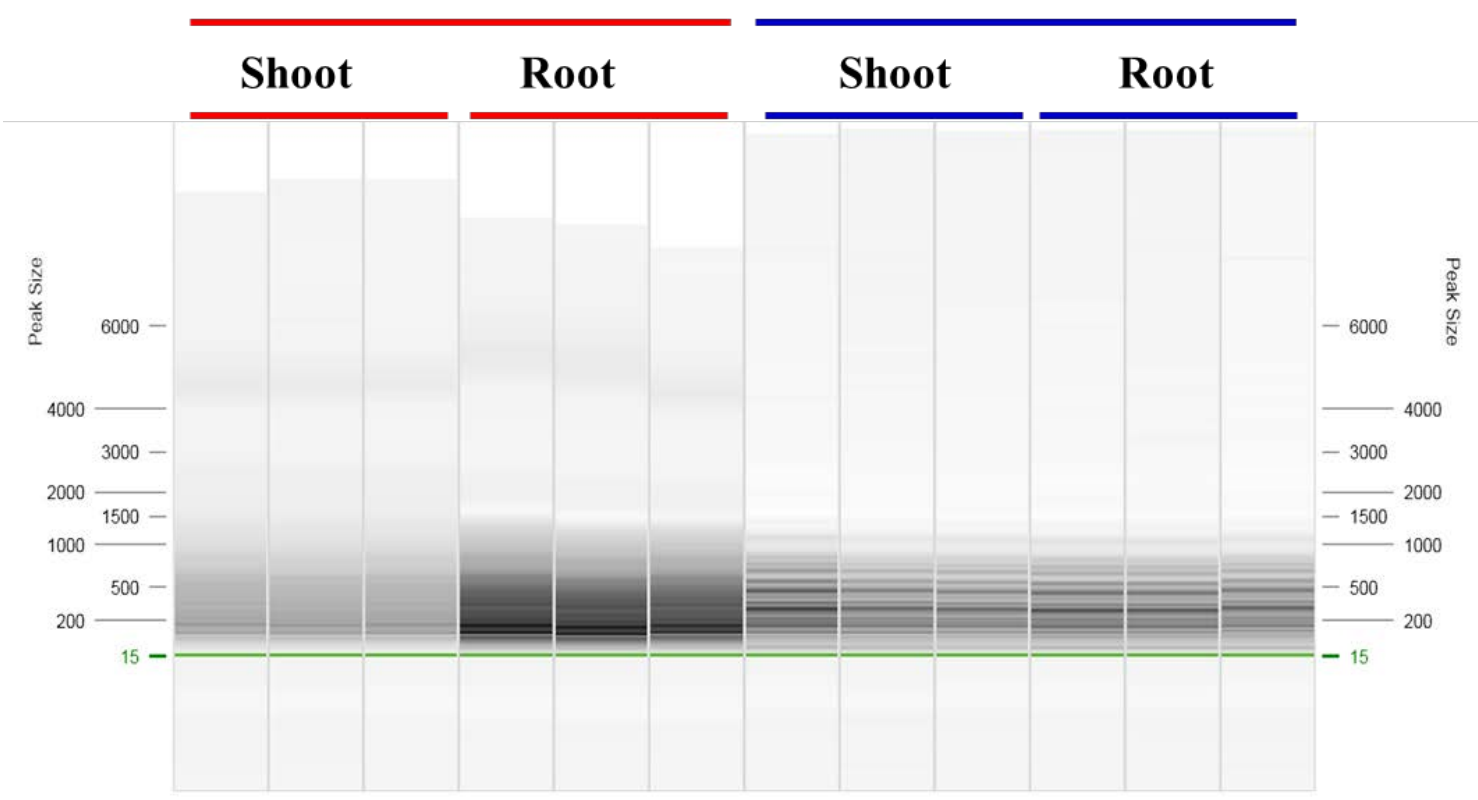

Figure 3B. Electropherogram of total RNA extracted from two-day-old Brassica rapa tissue after 70\% ethanol fixative was added gradually (slow fixation), or the tissue was immersed completely (fast fixation).

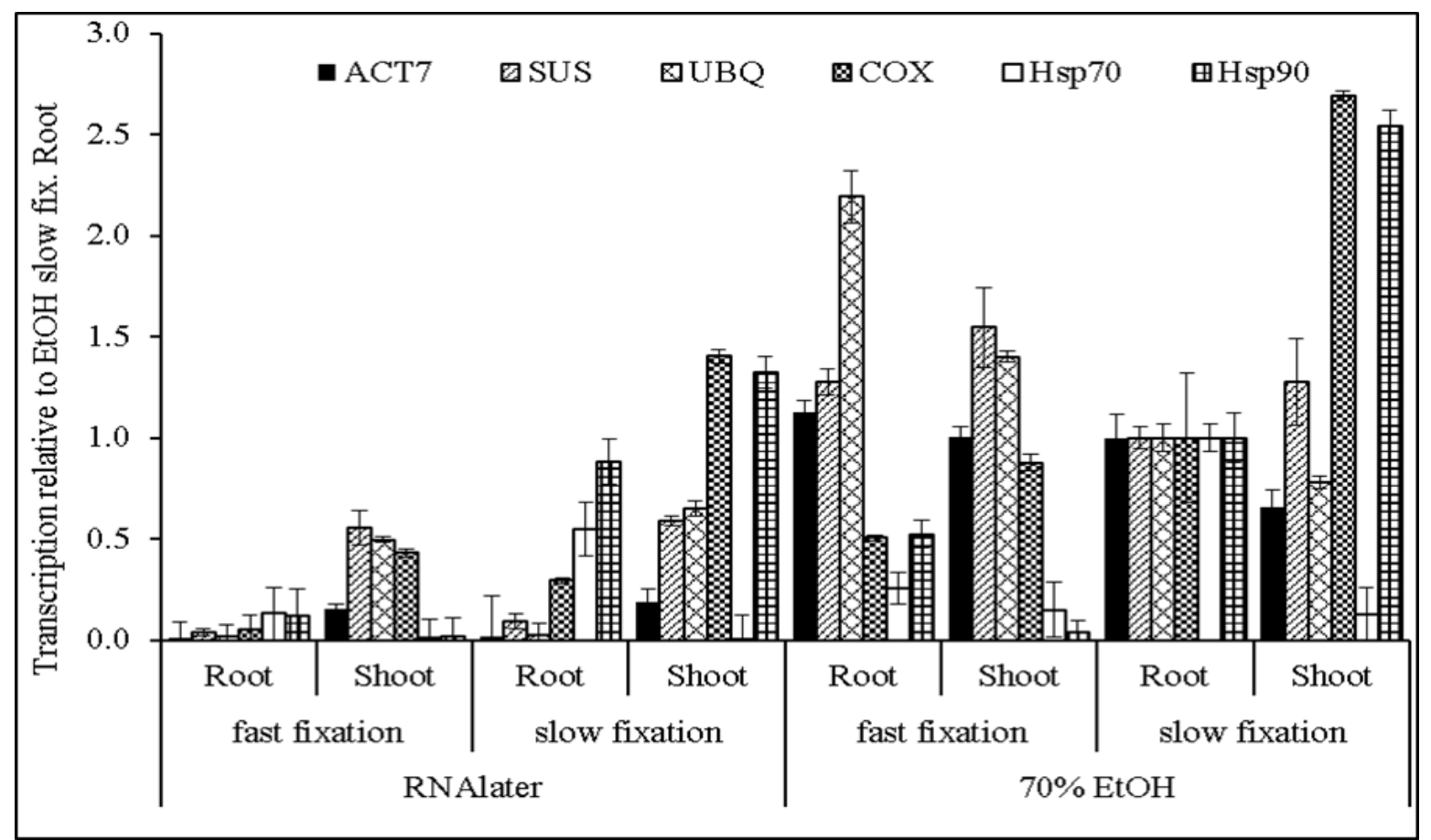

Figure 4. Comparison of gene transcriptions in Brassica rapa roots after fixation in $70 \%$ ethanol or RNAlater ${ }^{\circledR}$. The relative transcription levels were normalized to slow ethanol fixation of roots (i.e., set to ' 1 ') because this normalization resulted in the lowest dynamic range of all possible tissue/fixation combinations. 
Park and Hasenstein -- Fixation Artefacts

Table 3. Overall transcription levels for $70 \%$ ethanol and RNAlater ${ }^{\circledR}$-fixed roots and shoots of two-day-old Brassica rapa seedlings. The values represent the average fold-ratio of examined genes (ACT7, SUS, UBQ1, COX1, Hsp70, and Hsp90) between columns (stress/slow fixation) and rows (immediate, complete submersion in the respective fixative).

\begin{tabular}{|c|c|c|c|}
\hline \multirow{2}{*}{\multicolumn{2}{|c|}{ EtOH }} & \multicolumn{2}{|c|}{ Slow fixation } \\
\hline & & Root & Shoot \\
\hline \multirow{3}{*}{ 总 } & $\begin{array}{l}\text { Root } \\
\text { Shoot }\end{array}$ & 1.0 & 1.6 \\
\hline & RNAlater ${ }^{\circledR}$ & & \\
\hline & $\begin{array}{l}\text { Root } \\
\text { Shoot }\end{array}$ & 5.0 & 2.5 \\
\hline
\end{tabular}

The typical workflow for the analysis of environmental responses in plants requires the assessment of transcription (expression) of individual genes. We normalized the transcription levels of all examined genes to the shoot tissue of ethanol-fixed seedlings. Although any normalization is suitable, we chose this tissue normalization because it resulted in the lowest ratio (maximally/minimally transcribed genes) for all tissues, genes, and trea ${ }^{\circledR e n t s . ~ T h e ~ d i f f e r e n c e s ~}$ in the patterns of gene expression for shoot and root tissues were profound, independent of the chosen reference tissue, and were more pronounced in RNAlater®.

Comparing the overall effect of the fixation process and tissue (Table 3) shows that slow fixation did not affect transcription values of ethanol-fixed root tissue, but enhanced transcription of all genes to 1.6-fold for ethanolfixed shoot tissue. Slow fixation in RNAlater ${ }^{\circledR}$ enhanced transcription on average 5-fold for roots and 2.5-fold for shoot material, compared to 'fast' fixation in RNAlater ${ }^{\circledR}$. These trends can also be seen in Figure 4. While these values illustrate the overall effect of a fixation procedure, it is also important to consider fixation effects on individual genes. Regardless of fixative, slow or 'stressed' fixation strongly enhanced transcription of COX and Hsp90 in shoots and Hsp70 and Hsp90 in roots (Figure 4). Regardless of the fixation protocols, ACT7 transcription values were 11-fold higher in ethanol-fixed material than in RNAlater ${ }^{\circledR}$-fixed tissue.

Morphological differences between roots (no cuticle) and shoots (hydrophobic cuticle) are likely to affect the sensitivity of tissue to fixative penetration. The difference between average transcription level in slow vs. fast (control) fixation RNAlater ${ }^{\circledR}$ and ethanol fixation is highly significant $\left(\mathrm{F}_{1,23}=4.2, \mathrm{p}<0.001\right)$ and may be related to faster penetration of the non-ionic fixative. The greater uniformity between slow and fast fixation and higher transcription levels suggests that ethanol represents a desirable alternative for the fixation of plant material.

\section{DISCUSSION}

Any reporting of transcription or expression of specific genes depends on the relevance of the chosen genes to the investigated process. The rationale for using ACT7 in this study is based on its inclusion as a reference gene (Gilliland et al., 2003) and its sensitivity to osmotic, heat, and metal stress (Wang et al., 2014). Sucrose synthase (SUS) is strongly expressed during germination (Sun et al., 2013), involved in growth and cell wall formation (Jiang et al., 2015), and is highly expressed in meristems (Cheng et al., 2015), which makes SUS representative of the overall health of seedlings. UBQ1 is a commonly used reference gene that is stably expressed in Brassica (Xiao et al., 2012) and many other species (González-Verdejo et al., 2008; Mehdi Khanlou and Van Bockstaele, 2012). Cytochrome oxidase is a temperature and salt stress sensitive gene (Garcia et al., 2016; Stoll et al., 2013) that controls peroxidation processes and is an indicator for chilling stress (Liu et al., 2015). The molecular chaperones HSP70 and HSP90 are typical stress response elements in a variety of cellular locations (Cha et al., 2013) that are regulated at the 
transcriptional level (Ohama et al., 2016), respond to many types of stresses-including osmotic stress (Ndimba et al., 2005), and affect root growth through PIN-FORMED (PIN) protein distribution (D'Alessandro et al., 2015). Thus the chosen genes represent a meaningful selection that is useful for the characterization of fixationrelated processes. Despite the inclusion of potential reference genes such as ACT7 or UBQ, a comparison of expression levels based on reference genes similar to the 'Delta-Delta method' (Pfaffl, 2001) is not applicable because none of the examined genes remained unaffected by the different fixation procedures. A possible solution to this conundrum could be the correction of individual genes based on the averaging of the transcription levels of all examined genes. This approach was used for the data in Table 3; however, since the present investigation is based on only six genes that do not represent a common pathway or process, the data should not be used to infer that the same ratios or transcription changes apply to other genes or investigations.

Nonetheless, the data (Figure 2 - Figure 4) show that fixation is a critical aspect for the proper assessment of plant responses. Because fixation, especially in space, is often mechanized or programmed, it is important to consider the effect of the tissue, plant size, age, mass, and developmental stage when evaluating presumed space effects. Since many plant space experiments are performed with Arabidopsis seedlings, their size and specific growth performance depends on nutrients, light, and space conditions (reduced buoyancy driven gas exchange, a ${ }^{\circledR}$ ospheric composition including ethylene, volatile organic compounds, and uniform temperature). These diverse, often experiment-specific, parameters are likely to contribute to the variability of gene expression. However, the close relatedness between Arabidopsis and Brassica used in this study and the SpaceX-3 experiment, suggests that metabolism is similar and that the comparison between these species is justified. Fixation artefacts are likely to occur in other species as well.

Based on the high demand for space material, there is a tendency to increase the number of seeds per unit (petri dish) beyond what would be done in ground experiments. The high number of seedlings, irregular growth, and reduced alignment because of weightlessness conditions are all factors that contribute to difficulties during tissue fixation. A large number of seedlings may entrap air among seedlings, and delay effective fixation, especially in space experiments. Another concern is the dilution of fixative as it interacts with the agar substrate. Agar may also surround roots and therefore delay their fixation and extend the effective fixation time. A similar rationale applies to different species-larger diameter tissue takes longer to fix than smaller structures, partially because of dilution effects during the process.

When comparing the two tested fixatives, several advantages and disadvantages need to be pointed out. RNAlater ${ }^{\circledR}$ as a high ionic strength fixative is less likely to penetrate cuticle-covered shoot tissue as rapidly as root tissue. However, it has the advantage of not being flammable, which is especially relevant for space experiments. In contrast, ethanol is a more benign fixative; its induction of stress responses is much less compared with RNAlater ${ }^{\circledR}$. Both fixatives had a poor preservation of rRNA and thus would not result in a high RNA integrity number (RIN) or equivalent value (RNA Integrity Score, RIS). However, assessing transcription relies on mRNA levels, which are not used for the calculation of these parameters. In addition, compared with rRNA, polyadenylated (i.e., mRNA) is stabilized by numerous factors (Lafarga et al., 2009; Wu and Brewer, 2012) and the relatively large size of rRNA may lead to more extensive degradation than that of mRNA. Although high-quality RNA is certainly desirable, transcription studies may not depend on rRNA information. The higher transcription values after ethanol fixation are in contrast to the lower RNA yield (Figure 1), again indicating that RNA yield is not correlated with mRNA quality. The comparison between RNAlater ${ }^{\circledR}$ and $70 \%$ ethanol shows that RNAlater ${ }^{\circledR}$ strongly induced stress responses in shoot and root tissue. In contrast, 70\% ethanol has higher transcription values in control tissue, and relatively constant expression for ACT7, SUS, and UBQ1. The stress response is noticeable for COX and Hsp90; interestingly Hsp70 was only increased in shoots but not root tissue, regardless of fixative, so tissue-specific factors contribute to differences in transcription values. 
The response of tissue (Figure 4) shows that differences in fixation induce the very genes and most likely processes that are often found to be upregulated in space experiments, including elevated levels of heat shock proteins (Paul et al., 2005a; Wang et al., 2016; Zupanska et al., 2013), and oxidative (Kwon et al., 2015) and osmotic stress (Garcia et al., 2016). These data suggest that what is attributed to space may at least partially be the result of fixation-related issues. Similar effects of RNAlater ${ }^{\circledR}$ have also been reported in RNA stability studies of human placenta tissue (Fajardy et al., 2009).

Recent studies point out that gene activation has circadian components (Choudhary et al., 2016). Therefore, in addition to fixation-induced transcription, timing of experiments and time of fixation is likely to contribute to changes in gene expression. Of course, studies on diurnal phenomena in space are lacking, especially the effect of light and dark cycles and any related entraining. One might argue that dark-germinated and cultivated seedlings are not likely to show prominent periodic changes in gene expression. However, as long as such possibilities have not been investigated, such effects cannot be ruled out as contributing to the 'space syndrome' or differentially transcribed or expressed patterns of genes that the plant community is focused on resolving.

\section{CONCLUSIONS}

The termination of space experiments typically hinges on successful fixation of material for future ground-based analyses. We show that even after successful completion of an experiment, the process of fixation has the potential to induce numerous, difficult-todetermine artefacts that typically would be attributed to the space environment or stress responses. The results in no way denigrate RNAlater ${ }^{\circledR}$ as fixative, but show that fixation evaluation should be an integral part especially of space experiments. The awareness of fixationrelated problems should help separate space effects from artefacts.

\section{ACKNOWLEDGEMENTS}

This research was supported by NASA grant NNX10AP91G.

\section{REFERENCES}

Abbaraju NV, Cai Y, Rees BB (2011) Protein recovery and identification from the gulf killifish, Fundulus grandis: comparing snapfrozen and RNAlater ${ }^{\circledR}$ preserved tissues. Proteomics 11: 4257-4261

Almoguera C, Personat JM, Prieto-Dapena P, Jordano J (2015) Heat shock transcription factors involved in seed desiccation tolerance and longevity retard vegetative senescence in transgenic tobacco. Planta 242: 461-475

Botling J, Edlund K, Segersten U, Tahmasebpoor S, Engström M, Sundström M, Malmström PU, Micke P (2009) Impact of thawing on RNA integrity and gene expression analysis in fresh frozen tissue. Diagnostic Molecular Pathology 18: 44-52

Cha J-Y, Ahn G, Kim JY, Kang SB, Kim MR, Su'udi M, Kim W-Y, Son D (2013) Structural and functional differences of cytosolic $90-\mathrm{kDa}$ heat-shock proteins (Hsp90s) in Arabidopsis thaliana. Plant Physiology and Biochemistry 70: 368-373

Cheng J, Cheng X, Wang L, He Y, An C, Wang Z, Zhang H (2015) Physiological characteristics of seed reserve utilization during the early seedling growth in rice. Brazilian Journal of Botany 38: 751-759

Choudhary MK, Nomura Y, Shi H, Nakagami H, Somers DE (2016) Circadian profiling of the Arabidopsis proteome using 2D-DIGE. Frontiers in Plant Science 7: 1007

D'Alessandro S, Golin S, Hardtke CS, Lo Schiavo F, Zottini M (2015) The co-chaperone p23 controls root development through the modulation of auxin distribution in the Arabidopsis root meristem. Journal of Experimental Botany 66: 5113-5122

Dantán-González E, Rosenstein Y, Quinto C, Sánchez F (2001) Actin monoubiquitylation is induced in plants in response to pathogens and symbionts. Molecular Plant-Microbe Interactions 14: 1267-1273

Dunaeva M, Adamska I (2001) Identification of genes expressed in response to light stress in leaves of Arabidopsis thaliana using RNA differential display. European Journal of Biochemistry 268: 5521-5529

Dunmire V, Wu C, Symmans WF, Zhang W (2002) Increased yield of total RNA from 


\section{Park and Hasenstein -- Fixation Artefacts}

fine-needle aspirates for use in expression microarray analysis. BioTechniques 33: 890896

Fajardy I, Moitrot E, Vambergue A, VandersippeMillot M, Deruelle P, Rousseaux J (2009) Time course analysis of RNA stability in human placenta. BioMed Central (BMC) Molecular Biology 10: 21

Fengler S, Spirer I, Neef M, Ecke M, Nieselt K, Hampp R (2015) A whole-genome microarray study of Arabidopsis thaliana semisolid callus cultures exposed to microgravity and nonmicrogravity related spaceflight conditions for 5 days on board of Shenzhou 8. BioMed Research International 547495

Ferl RJ, Koh J, Denison F, Paul A-L (2015) Spaceflight induces specific alterations in the proteomes of Arabidopsis. Astrobiology 15: 32-56

Ferl RJ, Zupanska A, Spinale A, Reed D, Manning-Roach S, Guerra G, Cox DR, Paul A-L (2011) The performance of KSC Fixation Tubes with RNALater for orbital experiments: a case study in ISS operations for molecular biology. Advances in Space Research 48: 199-206

Garcia L, Welchen E, Gey U, Arce AL, Steinebrunner I, Gonzalez DH (2016) The cytochrome c oxidase biogenesis factor AtCOX17 modulates stress responses in Arabidopsis. Plant Cell and Environment 39: 628-644

Gilliland LU, Pawloski LC, Kandasamy MK, Meagher RB (2003) Arabidopsis actin gene ACT7 plays an essential role in germination and root growth. Plant Journal 33: 319-328

González-Verdejo CI, Die JV, Nadal S, JiménezMarín A, Moreno MT, Román B (2008) Selection of housekeeping genes for normalization by real-time RT-PCR: analysis of Or-MYB1 gene expression in Orobanche ramosa development. Analytical Biochemistry 379: 176-181

Grotzer MA, Patti R, Geoerger B, Eggert A, Chou TT, Phillips PC (2000) Biological stability of RNA isolated from RNAlater-treated brain tumor and neuroblastoma xenografts. Medical and Pediatric Oncology 34: 438442
Gupta V, Holets-Bondar L, Roby KF, Enders G, Tash JS (2015) A tissue retrieval and postharvest processing regimen for rodent reproductive tissues compatible with longterm storage on the International Space Station (ISS) and post-flight biospecimen sharing program. BioMed Research International $\mathbf{4 7 5 9 3 5}$

Jiang SY, Chi YH, Wang JZ, Zhou JX, Cheng YS, Zhang BL, Ma A, Vanitha J, Ramachandran S (2015) Sucrose metabolism gene families and their biological functions. Scientific Reports 5: 17583

Kittang A-I, Kvaløy B, Winge P, Iversen T-H (2010) Ground testing of Arabidopsis preservation protocol for the microarray analysis to be used in the International Space Station (ISS) European Modular Cultivation System (EMCS) Multigen-2 experiment. Advances in Space Research 46: 1249-1256

Kwon T, Sparks JA, Nakashima J, Allen SN, Tang Y, Blancaflor EB (2015) Transcriptional response of Arabidopsis seedlings during spaceflight reveals peroxidase and cell wall remodeling genes associated with root hair development. American Journal of Botany 102: 21-35

Lafarga V, Cuadrado A, Lopez de Silanes I, Bengoechea R, Fernandez-Capetillo O, Nebreda AR (2009) p38 mitogen-activated protein kinase- and HuR-dependent stabilization of p21(Cip1) mRNA mediates the G(1)/S checkpoint. Molecular and Cellular Biology 29: 4341-4351

Liu A, Chen S, Wang M, Wang Z, Zheng C, Zhao P, Guo D, Ahammed GJ (2015) Silencing of mitochondrial uncoupling protein gene aggravates chilling stress by altering mitochondrial respiration and electron transport in tomato. Acta Physiologiae Plantarum 37: 223

Mehdi Khanlou K, Van Bockstaele E (2012) A critique of widely used normalization software tools and an alternative method to identify reliable reference genes in red clover (Trifolium pratense L.). Planta 236: 13811393

Millar KD, Johnson CM, Edelmann RE, Kiss JZ (2011) An endogenous growth pattern of roots is revealed in seedlings grown in microgravity. Astrobiology 11: 787-797 


\section{Park and Hasenstein -- Fixation Artefacts}

Ndimba B, Rafudeen S, Gehring C, Meyer Z, Simon W, Chivasa S, Slabas A (2005) Proteomic identification of an hsp70.1 protein induced in Arabidopsis cells following hyperosmotic stress trea ${ }^{\circledR e n t s . ~}$ South African Journal of Science 101: 449453

Nsubuga AM, Robbins MM, Roeder AD, Morin PA, Boesch C, Vigilant L (2004) Factors affecting the amount of genomic DNA extracted from ape faeces and the identification of an improved sample storage method. Molecular Ecology 13: 2089-2094

Ohama N, Kusakabe K, Mizoi J, Zhao H, Kidokoro S, Koizumi S, Takahashi F, Ishida T, Yanagisawa S, Shinozaki K, YamaguchiShinozaki K (2016) The transcriptional cascade in the heat stress response of Arabidopsis is strictly regulated at the level of transcription factor expression. Plant Cell 28: $181-201$

Páska C, Bögi K, Szilák L, Tokés A, Szabó E, Sziller I, Rigó Jr J, Sobel G, Szabó I, KaposiNovák P, Kiss A, Schaff Z (2004) Effect of formalin, acetone, and RNAlater fixatives on tissue preservation and different size amplicons by real-time PCR from paraffinembedded tissue. Diagnostic Molecular Pathology 13: 234-240

Paul A-L, Levine HG, McLamb W, Norwood KL, Reed D, Stutte GW, Wells HW, Ferl RJ (2005b) Plant molecular biology in the space station era: utilization of KSC fixation tubes with RNAlater. Acta Astronautica 56: 623628

Paul A-L, Popp MP, Gurley WB, Guy C, Norwood KL, Ferl RJ (2005a) Arabidopsis gene expression patterns are altered during spaceflight. Advances in Space Research 36: 1175-1181

Pfaffl MW (2001) A new mathematical model for relative quantification in real-time RT-PCR. Nucleic Acids Research 29: e45

Pietsch J, Ma X, Wehland M, Aleshcheva G, Schwarzwälder A, Segerer J, Birlem M, Horn A, Bauer J, Infanger M, Grimm D (2013) Spheroid formation of human thyroid cancer cells in an automated culturing system during the Shenzhou-8 space mission. Biomaterials 34: 7694-7705
Riesgo A, Pérez-Porro AR, Carmona S, Leys SP, Giribet G (2012) Optimization of preservation and storage time of sponge tissues to obtain quality mRNA for nextgeneration sequencing. Molecular Ecology Resources 12: 312-322

Stoll B, Stoll K, Steinhilber J, Jonietz C, Binder S (2013) Mitochondrial transcript length polymorphisms are a widespread phenomenon in Arabidopsis thaliana. Plant Molecular Biology 81: 221-233

Sun YG, Wang B, Jin SH, Qu XX, Li YJ, Hou BK (2013) Ectopic expression of Arabidopsis hlycosyltransferase UGT85A5 enhances salt stress tolerance in tobacco. PLoS One 8: e59924

Wang SS, Sherman ME, Rader JS, Carreon J, Schiffman M, Baker CC (2006) Cervical tissue collection methods for RNA preservation: comparison of snap-frozen, ethanol-fixed, and RNAlater-fixation. Diagnostic Molecular Pathology 15: 144148

Wang X, Yan B, Shi M, Zhou W, Zekria D, Wang HZ, Kai G (2016) Overexpression of a Brassica campestris HSP70 in tobacco confers enhanced tolerance to heat stress. Protoplasma 253: 637-645

Wang Z, Chen Y, Fang H, Shi H, Chen K, Zhang $Z$, Tan X (2014) Selection of reference genes for quantitative reverse-transcription polymerase chain reaction normalization in Brassica napus under various stress conditions. Molecular Genetics and Genomics 289: 1023-1035

Wu X, Brewer G (2012) The regulation of mRNA stability in mammalian cells: 2.0. Gene 500: 10-21

Xiao D, Zhang N-W, Zhao J-J, Bonnema G, Hou $X-L$ (2012) Validation of reference genes for real-time quantitative PCR normalization in non-heading Chinese cabbage. Functional Plant Biology 39: 342-350

Zupanska AK, Denison FC, Ferl RJ, Paul A-L (2013) Spaceflight engages heat shock protein and other molecular chaperone genes in tissue culture cells of Arabidopsis thaliana. American Journal of Botany 100: 235-248 